\title{
The Problem of Ethnicity in Khaled Hosseini's The Kite Runner
}

\author{
Sofior Rahman Pramanik \\ Asstt Professor \\ West Goalpara College \\ Assam, India \\ sofior2000@gmail.com
}

\begin{abstract}
Ethnicity is a worldwide matter and is based on a cluster of personality originated from some ancestry and shares some common traits like language, culture, religion, rite and rituals of the society. Belonging to the same inherited status every member of the ethnic group share same dress -style and have similar physical appearance. "Ethnicity refers to a group of people who are of the same origin, history, values, attitude and behavior[ $\left.{ }^{1}\right]$.In every nation throughout the world, there are some ethnic group. Afghanistan is such a country where there is a large number of ethnic group like - Pashtuns, Hazara, Tajik, Uzbek, Aimak, Turkman,and Beloch etc. Khaled Hosseini's The Kite Runner set in Afghanistan and U.S.A. depicts the two major ethnic group of Afghanistan-Pashtuns and Hazara along with their social, cultural and religious conflict. In "The Kite Runner "the Pashtuns the largest ethnic group of the nation, run the country and have the power in their hands whereas Hazara are small in group are slave to them.
\end{abstract}

Keywords:-Ethnicity, Pashtuns ,Hazara, Conflict. 


\section{Introduction}

Colonization and immigration are the root cause for the development of ethnicity. In other words, ethnicity is the outcome of colonization and immigration. Since Afghanistan was the main trade route and invasion route between Central Asia and Southern Asia with Western Asia, the trader and business man settled here time to time and composed a multi ethnic nation. In a small country like Afghanistan there are around 30 million population as per census 2011and there are many ethnic group like - Pashtuns, Tajik, Uzbek, Hazara, Beloch and Turkman, Among the major ethnic group Pashtuns comprise $42 \%$ of the whole population following Tajik 27\%and Hazara with 10\% is third largest ethnic group of the Afghanistan. The plot of the Khalid Hosseini's novel "The Kite Runner " centers around the two major ethnic group Pashtuns and Hazara.

Amir, the protagonist of the novel with his wealthy father Baba represent Pashtuns ethnic group whereas their servant Ali and his son Hassan belongs to Hazara ethnic group. Although in Afghanistan, Hazara are treated inhumanly and look inferior to Pashtuns, but in the early part of the novel there were a harmonious relationship between this two family Baba-Amir and Ali- Hassan. Besides, Amir and Hassan were two intimate friend .But as the story progress, and when Soviet invaded Afghanistan, a distance is made between this two family as Amir with his father Baba went and settle in U.S.A .In America, the father- son faced some difficulties with some American who don't have positive view towards Afghans .However, at last Amir becomes a successful writer .At the end of the novel, Amir returned to Afghanistan and brings Hassan's son with himself to live with his family in America. Although the novel has many theme, but the present paper will analyse the problem of ethnicity in Afghan society. 


\section{Discussion:}

Since Afghanistan is a multi-ethnic nation, the objective of the present research is to analyse the ethnic views among Afghan as reflected in Khaled Hosseini's The Kite Runner The following explanations and analysis are provided to give an account to give a clear picture of ethnic views in Afghanistan. The theme of ethnicity is very clearly evident in the opening lines of the novel. In a flashback the narrator Amir returned to the age of twelve, on a winter of 1975.Here he says: I became what I am today at the age of twelve, on a frigid overcast day in the winter of 1975.I remember the precise moment, crouching behind a crumbling mud wall, peeking into the alley near the frozen Creek " ( Hosseini -1) Here in this flashback narrator Amir referred the very moment when Hassan was raped by a group of teenager leading Assef in an alley behind a mud wall. That Hassan was raped by Assef for being a Hazara clearly evident from the following remarks made by Assef: "There is nothing sinful about teaching a lesson to a disrespectful donkey ".(Hosseini-66)and " It is just a Hazara'(66). By referring to the sexual harassment to a Hazara by a Pashtuns at the beginning of the novel, the writer indulge the pathetic conditions of Hazara and negative attitude towards them.

As shown in "The Kite Runner " the Hazara are oppressed by Pashtuns. They were killed by Pashtun and were forced to leave their land and home and were considered as their slave. Amir said: I read that my people, the Pashtuns, had persecuted and oppressed the Hazaras.(Hosseini-8).Amir again said: The book said that my people had killed the Hazaras, driven them from their lands, burned their home and sold their women "" (Hosseini -8). The reasons for the inhuman behavior of Pashtuns towards Hazaras is their rise and rebillion against Pashtuns. The Hazaras arrived at Afghanistan in the 13th and 14th century and in 19th century the Hazaras had tried to rise against Pashtuns and the Pashtuns had "quelled them with unspeakable violence". Another reason for their violence and aggressive behavior 
towards Hazara was the different religious doctrines practice by Hazara. The majority Pashtuns followed Sunni philosophy of Islam whereas minority Hazara were Shi'a Muslim.

The above argument can be justified with the following remarks made by Amir. The following week, after class, I show the book to my teacher and pointed to the chapter on the Hazaras. He skinned through a couple of pages, snickered ,handed the book back. That the one thing Shi'aa people do well, "he said, picking up his papers," passing themselves, as martyrs. He wrinkled his nose when he said the word Shia' like it was some kind of disease "(Hosseini-8).

The Hazaras were the victims not only in society but also in educational institutions. As mentioned by Amir, the Hazaras were excluded from many social rights including the right to education. "School text books barely mentioned them and referred to their ancestry only in passing. Then one day I was in Baba's study room, looking through his stuff, when I found one of my mother's old history books..... and was stunned to find an entire chapter on Hazara history. An entire chapter dedicated to Hassan's people. In it I read my people the Pashtuns had persecuted and oppressed the Hazaras". (Hossaini-8). The U.S department of state country report on Afghanistan 2012 under titled " National/Racial/Ethnic Minorities ",illustrate ," ethnic tension between various group continued to results in conflict and killing. For example: in November riots occurred at Kabul University after Sunni students tried to prevent ethnic Hazara students from observing Shi'aate religious practices..... [ $\left.{ }^{3}\right]$

However, Hazaras were mocked and insulted for their racial and facial discrimination. This issue is clearly reflected from the speech of Amir. Amir said: It also said something I did know, like That people called Hazaras mice eating, flat nosed, load carrying donkeys. I had heard some of the kids in the neighbourhood yell these names to Hasan "" (Hosseini-8 ).They are called flat nosed, mice eating, and load carrying donkeys because of Hazaras Mongoloid 
features. Amir says: For years that I was all I knew about Hazaras that they were Mongol descendants and that they look little like Chinese people "(Hosseini-8).

From the above lines it is evident that Pashtuns were able to make a clear difference between Pashtuns and Hazaras. They did it to run and control the country. Some dishonest and stupid souls of the society convenience the Afghan people by false representation that Mongolian Hazaras are not equal to other Afghan. In The Kite Runner all the non Hazaras characters consciously or unconsciously accepted that Pashtuns are different from them and they are superior to Hazara.

In The Kite Runner, Amir and Hassan are representative of two opposite poles of the same society-the wealthy and the poor ,Sunni and the Shi'aa, Pashtuns and the Hazaras, powerful and the feeble. Although Amir never displayed his feelings of human difference, and the superiority of Pashtuns over Hazara, his father showed a different manner of himself towards Hazara: the curious things was, I never thought of Hassan and me as friend either not in the usual sense, anyhow. Never mind that we taught each other to ride bicycle with no hands........Never mind any of those. Because history is not easy to overcome. Neither is religion. In the end, I was a Pashtun and he was a Hazara, I was a Sunni and he was a Shi'aa and nothing was ever going to change that. Nothing. (Hosseini-22). Here Amir expose the ethnic relations in Afghan society. Though, Amir being a powerful individual from majority Pashtuns shows positive attitude towards minority ethnic group Hazara. But the society prevent them to this act .Thus , as shown in The Kite Runner the ethnic views is a source of chaos in the society.

Assef, one of the major characters in "The Kite Runner "strongly dislikes Hazara and he seeks their elimination from Afghanistan. In The Kite Runner, Assef is determined to remove all Hazara from Afghanistan as he thought Afghanistan is the land of Pashtuns and Pashtuns were the real heiress of Afghanistan. Considering them (Hazara) garbage ,he wanted 
to clear. To fulfill this mission, he joined Taliban. Assef also blamed Amir and his father Baba and calls them 'disgrace of Afghanistan', for their support to Hassan and Ali- because they are Hazara. This hatred leads him to kill many Hazaras in Hazarajat, the hometown of Hazaras ethnic group, which he regarded as honour to the nation.

All the above discussion shows that 'ethnicity' is one of the major problems of Afghanistan. But it is not insolvency. It can be solved. There are some signs in "The Kite Runner "that reveals this problem can be solved and Afghanistan can be united .For instance we can raise the relationship between Amir and Hassan. Amir from Pashtuns and Hassan from Hazara ethnic groups both of them sacrifices for their relationship.

\section{Conclusion}

It can be concluded that' ethnicity' is a social outcome rather than biological difference. It makes a powerful negative impact on society, violates human rights, destroys social unity, brings social discrimination and thus imbalances society. Majority of ethnic groups with their power tries to control society and establishes their superiority. In The Kite Runner, Hosseini shows this through the inhuman behavior of majority Pashtuns over minority Hazara. 


\section{References}

N.R.Yetman,Majority and Minority: The Dynamics of race and ethnicity in American Life, Allyn and Bacon,Massachusetts,1999.

.Husseini, Khalid. The Kite Runner: Bloomsbury Publishing, London, 2003.Print.

U.S.Department of state 2012country Report on Human Rights Practices. 19 April/2013.P.45. 